A N N A L E S

UNIVERSITATIS M ARIAE CURIE-SKŁODOWSKA

LUBLIN - POLONIA

VOL. LXIII, 2

SECTIO C

2008

\title{
JOANNA SENDER
}

Department of Landscape Ecology and Nature Protection, University

of Nature in Lublin, Dobrzańskiego 37, 20-269 Lublin

e-mail: joanna.sender@up.lublin.pl

\section{Differentiation of the vegetation of the Szum river (Central Roztocze)}

Zróżnicowanie roślinności rzeki Szum (Roztocze Środkowe)

\section{SUMMARY}

Rivers play a very important role in the retention and transportation of water. The properties of river waters change in time and space. The unique feature occurring in rivers is matter and energy flow in one direction together with a river course. Such features as: river gradient, turbulent motion die down and the quantity of dragged material decreases. Because habitat conditions in each part of a river are different, the distribution (toposequence) of macrophytes is unique. In the last zone of the river habitat conditions are the most favorable to macrophytes development.

The investigation were carried out in one of the most interesting rivers in Central Roztocze the river Szum. The floristic analysis and basic physical and chemical parameters were examined with typical methods of hydrobiology.

The results of investigations show the clear differentiation of habitat and floristic conditions along the river course. The specific toposequence of water vegetation in each research sites of the river Szum showed the differentiation of habitat conditions too. The highest differentiation of plant communities occurred in places being under the largest influence of the human pressure. It is also reflected in the highest value of the synanthrophic index. The river Szum creates good habitat conditions for the development of riparian vegetation, however water macrophytes were poor, so they did not find here convenient conditions for the development.

\section{STRESZCZENIE}

Rzeki to śródlądowe zbiorniki wodne, pełniące istotną rolę w retencji i transporcie wody. Właściwości wód rzecznych zmieniają się w czasie i przestrzeni. Osobliwą cechą jest to, że przepływ materii i energii dokonuje się w jednym kierunku, wraz z biegiem rzeki. Zmieniają się także ta- 
kie cechy, jak: spadek podłużny rzeki, słabnie ruch turbulentny, zmniejsza się ilość wleczonego materiału. W związku z oferowanymi warunkami w poszczególnych odcinkach biegu rzeki toposekwencja makrofitów jest specyficzna. Z reguły w ostatniej strefie rzeki panują najdogodniejsze warunki do rozwoju roślinności wodnej i wodno-bagiennej.

Badaniami objęto jedną z najciekawszych rzek Roztocza Środkowego - rzekę Szum. Badania właściwości fizyczno-chemicznych wody oraz struktury jakościowej i ilościowej makrofitów prowadzono metodami typowymi dla badań hydrobiologicznych. Wyniki badań wskazują na wyraźne zróżnicowanie warunków siedliskowych i florystycznych wzdłuż biegu rzeki. Wyrazem tego była specyficzna toposekwencja roślinności wodnej. Największe zróżnicowanie zbiorowisk roślinności wodnej występowało w miejscach będących pod największym wpływem oddziaływań człowieka, czego odzwierciedleniem była także najwyższa wartość wskaźnika synantropizacji dla tych stanowisk. Jest to rzeka, w której panują dobre warunki do rozwoju roślinności lądowo-wodnej, natomiast ubogi jest skład roślin typowo wodnych, które nie znajdują tu dogodnych warunków do rozwoju.

Key words: macrophytes, river, water plant communities, toposequence

\section{INTRODUCTION}

Roztocze connects the Lublin Upland with the Podole, appearing as the ridge running from the northern-west to the south-east. The whole area of Roztocze is built from the rocks Cretaceous origin such as: marls, gaizes and limestones. The next layers create Tertiary deposits - sands and limnestones, as well as Quaternary deposits like sands and loess (Buraczyński 1974).

One of the most beautiful places of Central Roztocze is the area border on the Sandomierska Valley. The Roztoczańskie hills overlook the sandy Puszczańska Plain which is covered with the great complex of the forests of the Solska Forest. The considerable part of the Forest, as well as the edge of Roztocze are within the Landscape Park Solska Forest. The deeply cut into the ravined river valleys makes the landscape very attractive. They are protected. The sources of the rivers there are in Roztocze, then flowing down towards the Solska Forest. These are: upper Tanew with its tributaries, Jelen, Sopot and Szum with Nepryszka tributary. These valleys in the edge zone have steep slopes. They are covered with virgin mixed forest; with the large quantity of rare plant species in the undergrowth, especially mountain species. The Roztoczańskie rivers in the revined river stretch turned into a rushing mountain stream. The water breaks on numerous stones and rock steps forming cataract and the small cascade. There are a lot of historical monuments in all river valleys.

The catchment of the river Szum with water reservoir and small power station in Górecko Kościelne covers $30 \%$ of the district surface.

Along the revined river Szum stretch on the surface 18.03 ha there is Landscape Reserve "Szum" established in 1958. It is situated in the protection zone of the Roztoczański National Park. Nearly two kilometers of the river valley is protected. The bottom of the valley overgrows riparian forest and wet leafy forest, when the hillsides upland are covered with mixed fir forest with admixture of spruce and pine. In upland areas it turns into pine forest (Czarnecka, Janiec 2002).

Rare plant species occur in the reserve, among them numerous protected species such as: Aruncus silvestris, Chimaphila umbellata, Drosera rotundifolia, D. intermedia, Galanthus nivalis, Hedera helix, Lilium martagon, Lycopodium annotinum, L. clavatum, L. selago, Equisetum maximum, Cystopteris fragilis, Polypodium vulgare, as well as Asplenium trichomanes and Ribes alpinus.

Rivers fill the essential role in water retention and water transport. The properties of river waters change in time and space.

The unique feature occurring in rivers is matter and energy flowing in one direction together with river course. Such features as: river gradient, turbulent motion die down and the quantity of 
dragged material decrease (Richards 1982). Because the habitat conditions in each part of the river are different, distribution (toposequence) of macrophytes is unique. Hepaticea and some water mosses appear as first. Along the next stretch of the river macrophytes with flexible sprouts occur, whereas edges are covered with water - swampy macrophytes. In the last stretch of the river habitat conditions are the most favourable to macrophytes development (Amors, Petts 1993).

In Polish rivers, taking into consideration aquatic flora (without algae), most often occur vascular plants (Cormophyta), rarely Bryophytes (Bryophyta). But extremely rare in the rivers are Charales. Mainly macrophytes settle in narrow, shallow and slowly flowing rivers and their variety grows together with a river course.

The aim of investigations was to determine the differentiation of vegetation structure under changing habitat conditions in the river Szum

\section{MATERIAL AND METHODS}

The investigations of physical and chemical properties of water as well as qualitative and quantitative structure of macrophytes in the river Szum were carried out in summer 2005 and 2006. Research stands were arranged along the whole river - from the sources to the river-mouth. Together there were 5 research stands: the Swamp Międzyrzeki - the outflow, the river Szum - the outflow from the Roztoczański National Park, Górecko Kościelne, the river Szum - below the ponds, mouth of the river Szum to the river Tanew (Fig 1).

At the same time the floristic analysis and the basic physical and chemical parameters were examined.

Water quality was characterized by reaction $(\mathrm{pH})$, temperature, conductivity, suspension, dissolved oxygen, total N, and total P concentration. These variables were analyzed according to Polish Standards (Hermanowicz, Dojlido 1999).

Total length of the investigated river was $12 \mathrm{~km}$. A list of plant species was prepared for each stand area, with indication of species coverage, using Braun-Blanquet's scale (Pawłowski 1977).

Biodiversity was measured with the use of Shannon-Waewer index. Moreover, the synantrophic index was determined (Wysocki, Sikorski 2002).

\section{RESULTS AND DISCUSSION}

The analysis of the physical and chemical parameters of water at the examined stands in the river Szum shows the distinct differentiation along the river course. The highest values of water reaction, temperature, percent of oxygen and conductivity were observed in the riverheads stretch. However, the total P concentration was the lowest in this stretch. Together with the river course the temperature of water and conductivity increased. The quantity of the suspension and nutrient content were changing on the next research stands (Tab. 1). 


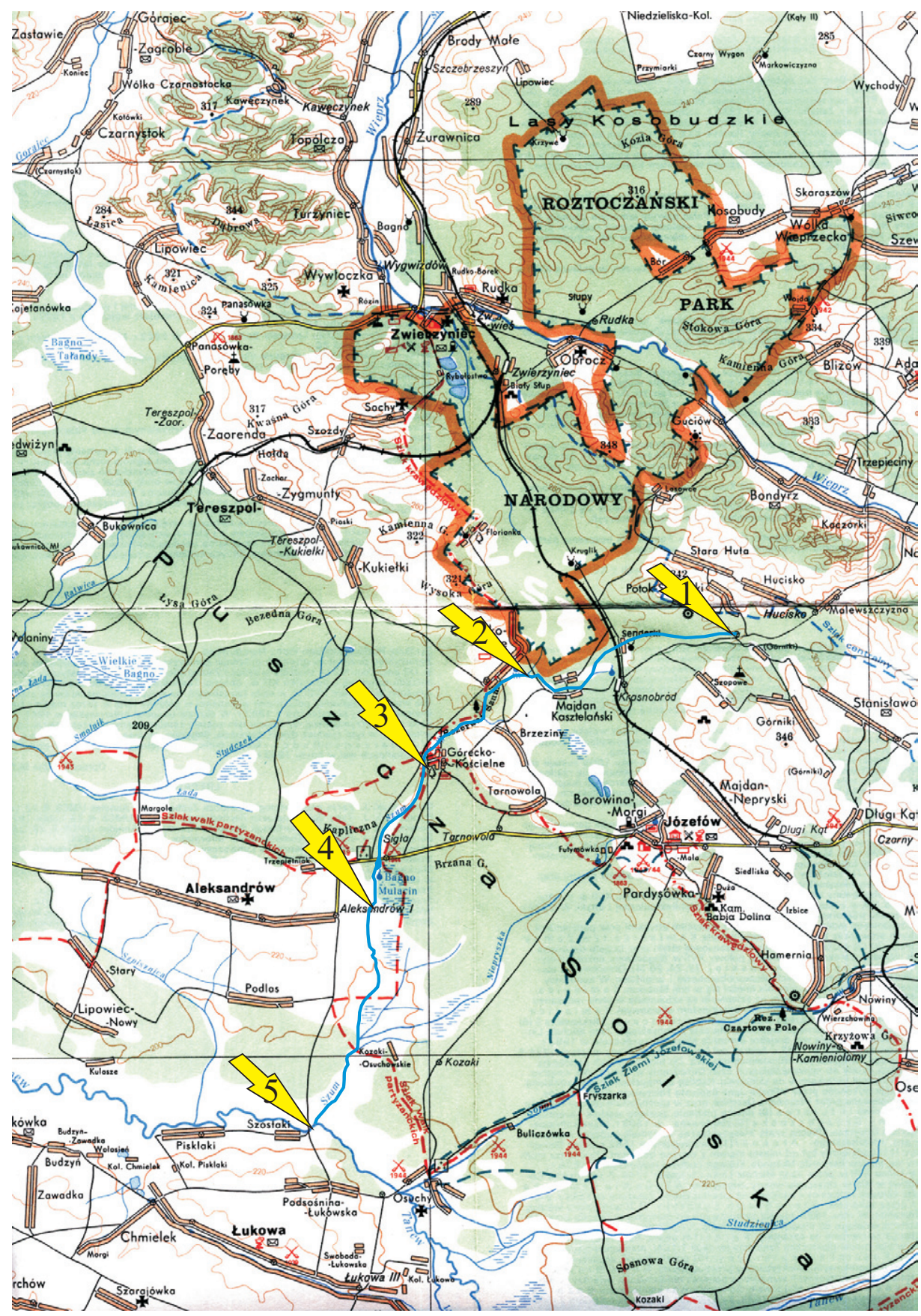

Fig. 1. Distribution of research stations in the river Szum (1 - the Swamp Międzyrzeki - the outflow, 2 - the river Szum - outflow from the RNP, 3 - Górecko Kościelne, 4 - the river Szum - below the ponds, 5 - mouth of the river Szum to the river Tanew) 
Table 1. Physical and chemical parameters of water at the examined stands in the river Szum $(2005,2006)$

\begin{tabular}{|c|c|c|c|c|c|c|c|c|c|c|}
\hline \multirow{2}{*}{ Parameters } & \multicolumn{2}{|c|}{$\begin{array}{l}\text { The Swamp } \\
\text { Międzyrzeki }\end{array}$} & \multicolumn{2}{|c|}{$\begin{array}{l}\text { The river Szum - } \\
\text { outflow from the } \\
\text { RNP }\end{array}$} & \multicolumn{2}{|c|}{$\begin{array}{l}\text { Górecko } \\
\text { Kościelne }\end{array}$} & \multicolumn{2}{|c|}{$\begin{array}{l}\text { The river Szum } \\
\text { - below the } \\
\text { ponds }\end{array}$} & \multicolumn{2}{|c|}{$\begin{array}{c}\text { Mouth of the river } \\
\text { Szum } \\
\text { to the river Tanew }\end{array}$} \\
\hline & 2005 & 2006 & 2005 & 2006 & 2005 & 2006 & 2005 & 2006 & 2005 & 2006 \\
\hline Suspension & 2.5 & & 9.2 & & 2.4 & & 9.5 & & 9.5 & \\
\hline Water reaction & 7.2 & 6.11 & 6.3 & 7.17 & 6.94 & 7.25 & 7.14 & 6.67 & 7.4 & 6.98 \\
\hline $\begin{array}{l}\text { Temperature of } \\
\text { water }\end{array}$ & 12.7 & 14.5 & 13.5 & 14.3 & 17.6 & 17.6 & 19.5 & 20 & 20.1 & 20 \\
\hline Conductivity & 152 & 149 & 253 & 280 & 292 & 316 & 265 & 281 & 308 & 284 \\
\hline$\% \mathrm{O}_{2}$ & 73.8 & 59.6 & 81.7 & 73.0 & 86.2 & 76.2 & 76.4 & 83.6 & 79.2 & 83.4 \\
\hline $\mathrm{N}-\mathrm{NH}_{4}$ & 0.053 & & 0.083 & & 0.024 & & 0.068 & & 0.038 & \\
\hline $\mathrm{N}-\mathrm{NO}_{3}$ & 0.801 & & 3.366 & & 4.367 & & 2.735 & & 2.474 & \\
\hline $\mathrm{PO}_{4}$ & 1.14 & & 0.179 & & & & 0.121 & & 0.163 & \\
\hline P tot. & 6.147 & & 0.523 & & 0.667 & & 0.128 & & 0.069 & \\
\hline
\end{tabular}

The vegetation of the river Szum and terrains directly adjacent made up 16 plant communities (Tab. 2). In another Polish river valleys there were determined seven plant associations (Gamrat 2006).

The highest diversity of plant communities was observed in two research sites in Górecko Kościelne and in the sites below the ponds, where occured as many as 8 communities. Whereas the lowest number of plant communities was observed in the river Szum near the outflow from the Roztoczański National Park, as well as in the mouth of the river Szum to the river Tanew (Tab. 2).

Toposequence that is following after oneself plant communities in space (Szmeja 2006).

Toposequence or distribution of plant communities, in each research stands of the river Szum showed the differentiation of habitat conditions enabling the development of all sorts of communities. So that the most favorable conditions were observed in two sites: Górecko Kościelne and the position below the ponds (Fig. 2).

The distinguished plant associations included 50 species in total. This is relatively high differentiation, because in other investigated rivers occurred from 30 to 36 species (Baattrup-Pedersen et al. 2002). The straight majority, because as many as 45 species belonged to riparian vegeration. The remaining species belonged to submerged and lemneid macrophytes. The number of species was different on research stands. The riparian vegetation predominated on every one. They are very important because of creating ecotone zone (Kłosowski, Tomaszewicz 1996). Both plant communities and the number of species occurring in the river bed were high in the same research sites (Górecko Kościelne and by the mouth of the river Szum to the river Tanew). The highest variety of species was observed in site below the ponds (Fig. 3). 
Table 2. Plant communities in some research stands in the river Szum

\begin{tabular}{|c|c|c|c|c|c|}
\hline Plant community & $\begin{array}{c}\text { The Swamp } \\
\text { Między- } \\
\text { rzeki }\end{array}$ & $\begin{array}{c}\text { The river } \\
\text { Szum - } \\
\text { outflow from } \\
\text { the RNP }\end{array}$ & $\begin{array}{c}\text { Górecko } \\
\text { Kościelne }\end{array}$ & $\begin{array}{l}\text { The river } \\
\text { Szum } \\
\text { below the } \\
\text { ponds }\end{array}$ & $\begin{array}{l}\text { Mouth of the } \\
\text { river Szum } \\
\text { to the river } \\
\text { Tanew }\end{array}$ \\
\hline \multicolumn{6}{|l|}{ Riparian vegetation } \\
\hline Caricetum acutiformis Sauer 1937 & & & + & + & \\
\hline Caricetum rostratae Rubel 1912 & + & & + & & \\
\hline Thelypteridi-Phragmitetum Kuiper 1957 & & & + & + & \\
\hline Molinietum-caeruleae W. Koch. 1926 & & & + & & \\
\hline Oeantho-Rorippetum Lohm 1950 & & + & + & + & \\
\hline Scirpetum silvatici Ralski 1931 & & & + & & \\
\hline $\begin{array}{l}\text { Phalaridetum arundinaceae (Koch. } 1926 \text { n.n) } \\
\text { Libb. } 1931\end{array}$ & & & & + & \\
\hline $\begin{array}{l}\text { Phragmitetum australis (Gams. 1927) } \\
\text { Schmale } 1939\end{array}$ & & & & + & \\
\hline $\begin{array}{l}\text { Sparganio-Glycerietum fluitantis Br.-B1. } 1925 \\
\text { n.n }\end{array}$ & & + & & + & \\
\hline Sagittario-Sparganietum emersi R.Tx. 1953 & & & & + & \\
\hline $\begin{array}{l}\text { Sphagnetum magellanici (Malc. 1929) } \\
\text { Kastner et Flossner } 1933\end{array}$ & + & & & & \\
\hline Caricetum elatae Koch 1926 & & & & & + \\
\hline Caricetum lasiocarpae Koch 1926 & + & & & & \\
\hline \multicolumn{6}{|l|}{ Water } \\
\hline $\begin{array}{l}\text { Ranunculetum circinati (Bennema et West. } \\
\text { 1943) Segal } 1965\end{array}$ & & & + & & \\
\hline Fontinalis antipyreticae Kaiser 1926 & & & + & & \\
\hline \multirow[t]{2}{*}{$\begin{array}{l}\text { Elodeetum canadensis (Pign. 1935) Pass } \\
1964\end{array}$} & & & & + & + \\
\hline & 3 & 2 & 8 & 8 & 2 \\
\hline
\end{tabular}

Different share of synanthropic species on individual sites confirms the differentiation of the river vegetation. This is also the appointment test of anthropogenic vegetation patches. The water and riparian vegetation showed in three studied sites in the river Szum a slight degree of transformation. The value of the synantrophic index amouting for the river Szum on the outflow from the Roztoczański National Park A $=0.06$ and in Górecko Kościelne $\mathrm{A}=0.12$, as well as below the ponds $\mathrm{A}=0.13$ proves it.

Small, shallow area of banks, bordering directly with the marshy meadows communities are the natural place of the water vegetation occurrence in the flow waters. The speed of the flow is the main factor differentiating the occurrence of plant communities. The arrangement of phytocenosis is clearly linear, right with the movement of water. As a rule near the shallow banks high and cyperaceous rushes occur. The rushes in the rivers are less differentiated than in lakes. They 

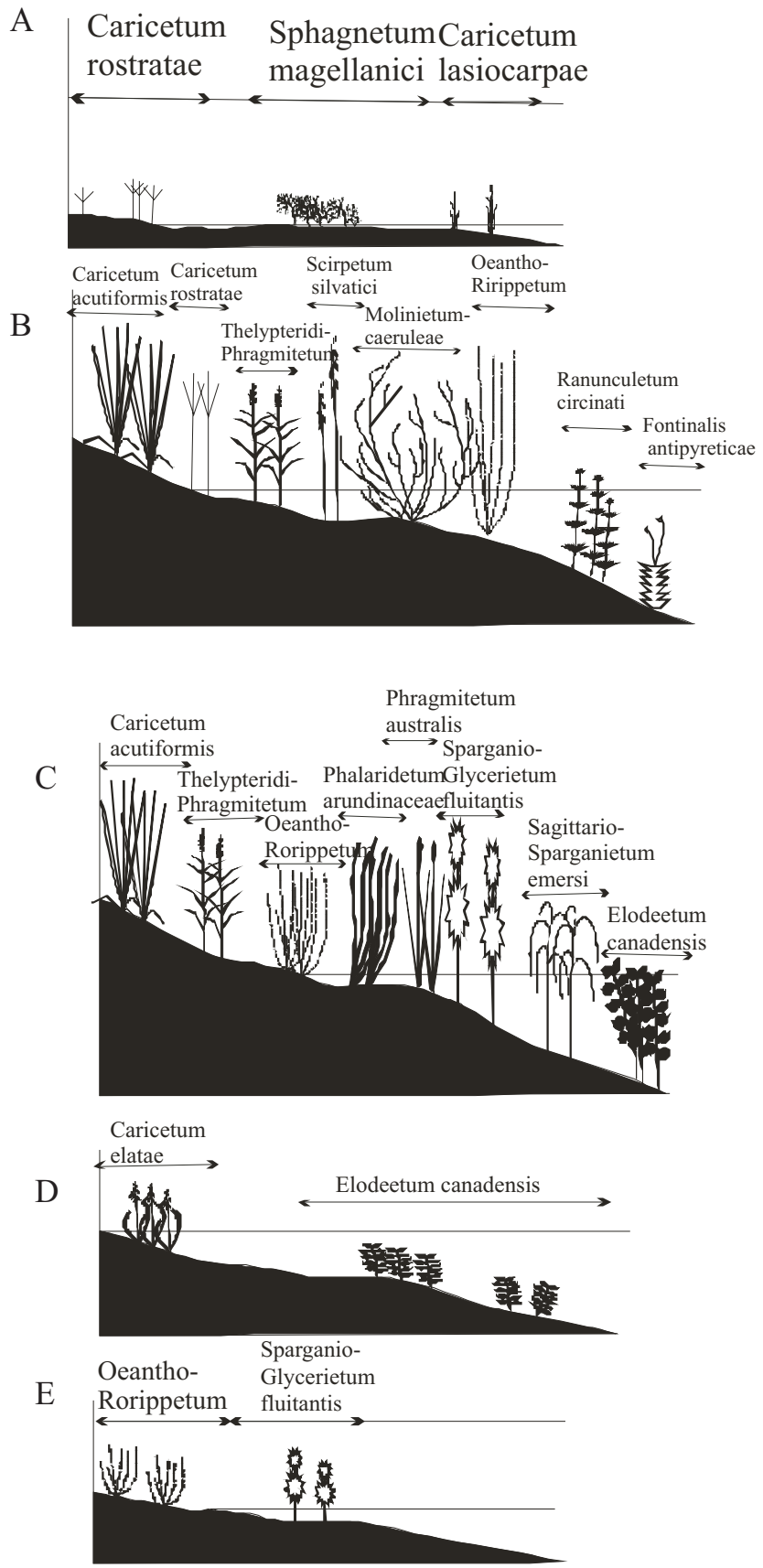

Fig. 2. Toposequence of plant communities in each research sites of the river Szum A - the Swamp Międzyrzeki - the outflow, B - the river Szum - outflow from the RNP, C - Górecko Kościelne, $\mathrm{D}$ - the river Szum - below the ponds, E - mouth of the river Szum to the river Tanew 
do not create continuous arrangements and cover considerably smaller surfaces (Wysocki, Sikorski 2002). In the course of the river where the flow is slow the submerged macrophytes can develop.

The width of patches of plant communities was different and the highest in places where the river banks were gentile. First of all the zone arrangement of vegetation in rivers depends on the current hydrological situation as well as river erosion or accumulation of the organic and mineral material. The variety of plants increases together with the river course. There are several reasons for the increasing plant diversity, among other things: the quantity of accumulated mineral and organic matter grows, the river bed is more wide and flattened, the speed of flow drops and the growth of its fecundity. The gentle valleyside slope angle and wide enough soft banks are covered with emergent macrophytes, whose diversity increases with the river course. The structure of water vegetation in the river also depends on the intensity and kind of human pressure on the river and its valley (Szmeja 2006).

The biomass of macrophytes in the river Szum was low and ranged from $12 \mathrm{~g} \cdot \mathrm{m}^{-2}$ to $48 \mathrm{~g} \cdot \mathrm{m}^{-2}$ (Fig. 4). The average biomass in Łęczyńsko-Włodawskie Lakes amounts to $370 \mathrm{~g} \cdot \mathrm{m}^{-2}$ (Sender 2006).

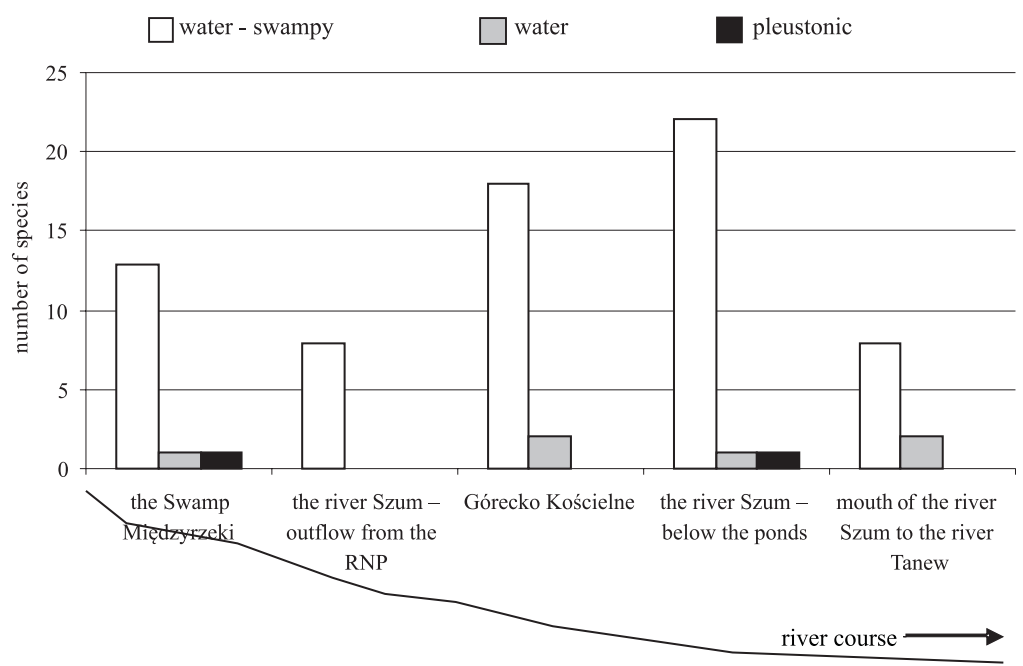

Fig. 3. Number of species in the investigated stands in the river Szum

This average productivity shows that the surrounding area of the river are little fertile and form the barrier from substances flowing from the catchment. The forest makes up the protection of the river and reduces the seasonal temperature fluctuations. 


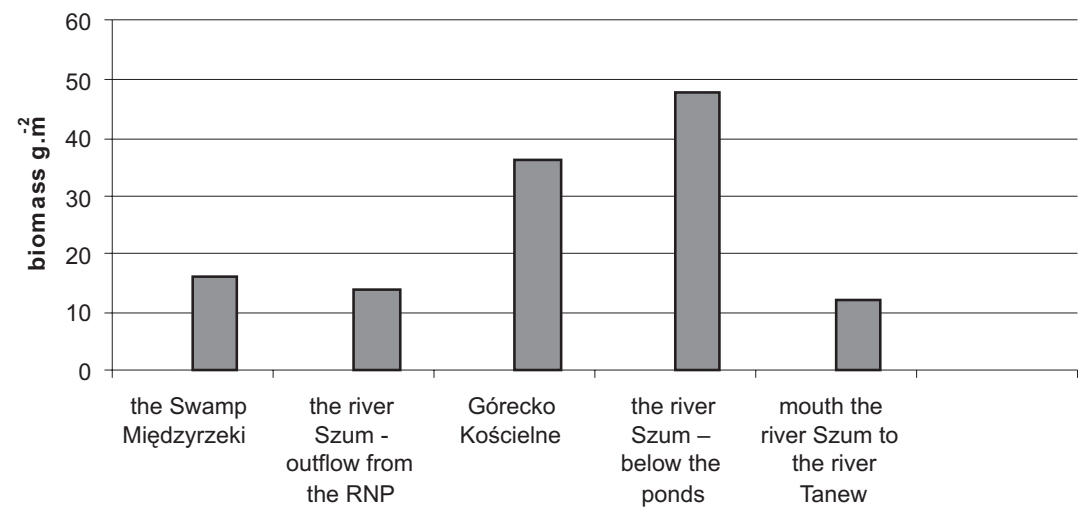

Fig. 4. Biomass of emergent and submerged macrophytes occurring in the river Szum

The temperature and solar radiation are important factors influencing the macrophytes development. These factors could have a significant influence on the structure of vegetation in the river Szum. The average width of the river bed was changing and ranged from $1.5 \mathrm{~m}$ on the position near outflow from the RNP, and $3 \mathrm{~m}$ on the position below ponds, to $3.4 \mathrm{~m}$ in Górecko Kościelne. The maximum depth of the river amounts to $1 \mathrm{~m}$, however visibility on each research sites was to the bottom. The bottom in the predominant majority was sandy and muddy with sand character. All these factors had a large influence on the development of water plants.

The river ecosystems create very changeable conditions. In the river Szum habitat conditions very often limit the development of macrophytes in the river bed.

\section{REFERENCES}

1. Amoros C., Petts G.E. (eds.) Hydrosystemes fluviaux. Collection d'Ecologie 24. Masson Paris, Milan, Barcelona, Bonn.

2. Baattrup-Pedersen A., Larsen S. E., Riis T. 2002. Long term effects of streams management on plant communities in two Danish lowland streams. Hydrobiol. 481: 33-45.

3. Buraczyński J. 1974. The outline of Roztocze Rawskie geomorphology. Annales UMCS sec. B, vol. XXIX: s. 47-76.

4. Gamrat R. 2006. Environmental evolution in a section of the Warta river valley. Acta Agrophisica 1(1): 31-37.

5. Hermanowicz W., Dojlido J.R. 1999. Physiochemical Analysis of Water and Waste Water (in Polish). Arkady Press, Warszawa.

6. Kłosowski S., Tomaszewicz H. 1996. Communities of the shore vegetation of the Krutynia river-lake system. Zesz. Nauk. „Człowiek i Środowisko” 13: 345-376. 
7. Pawłowski B. 1977. Composition and structure of plant communities and methods of their study (in Polish). [In:] Szafer W., Zarzycki K. (eds.) Plant Vegetation in Poland. T. I, PWN, Warszawa, s. 237-268.

8. Richards K. 1982. Rivers. Form and Process in Alluvial Channels. Methuen. London.

9. Sender J. 2006. Phytolittoral of some lakes in Iławskie and Łęczyńsko-Włodawskie Lake Districts. Teka v. III, p. 160-169.

10. Szmeja J. 2006. Guide to the Investigations of Water Vegetation. Uniw. Gdański.

11. Wysocki C., Sikorski P. 2002. Phytosociology Opplied. SGGW Press, Warszawa, pp. 449.

12. Czarnecka B., Janiec B. 2002. River fractures of Roztocze, as model objects in the ecological education, Wyd. UMCS, pp. 231. 